\title{
CHEMICAL MANIPULATION OF HILL COUNTRY PASTURES TO PRODUCE LEGUME DOMINANCE
}

M.P. ROLSTON, D.A. CLARK and BP. DEVANTIER

Grasslands Division, DSIR, Palmerston North

\section{Abstract}

Hill country pasture was sprayed with low fates of the herbicides paraquat, sethoxydim or Dowco 453 in late November. Legume content of the pasture 6 weeks after application increased from 29 to $61 \%$, and from 12 to $31 \%$ in January 1983 and 1984 respectively. The chemicals reduced dry matter yields by 16 and $45 \%, 6$ weeks after treatment, but yields were not reduced in subsequent harvests. The chemicals reduced dead matter content, strongly suppressed grass seed head production, increased clover seed head density and increased in vitro digestibility. Sethoxydim at high rates $150 \mathrm{~g} / \mathrm{ha}$ reduced perennial ryegrass (Lolium perenne) content, but Dowco 453 increased perennial ryegrass and decreased browntop (Agrosfis tenuis) content. The effect of clover content and dead matter on sheep diet selection is shown and the implications of these results for management of hill country pastures in moist summers are discussed.

Keywords: herbicide, paraquat, sethoxydim, Dowco 453, white clover, Trifolium repens, hill country, in vitro digestibility, perennial ryegrass, Lolium perenne ryegrass, Lolium perenne browntop, Agrostis tenuis.

\section{INTRODUCTION}

Surplus herbage accumulation in late spring and early summer is common in hill country. Typically during this period, pasture production may increase 12 fold, while animal requirements may increase 5 fold (Lambert \& Clark 1981). During November to April each millimetre of rainfall can increase herbage accumulation by $11 \mathrm{~kg}$ dry matter/ha (Lambert et al. 1983). Where herbage conservation is not possible because of contour, the development of long pastures in reproductive growth in excess of animal requirements represents a wastage of feed quantity and quality, and may present problems of pasture reversion, low plant density and poor stock performance (Suckling 1975, Korte 1982) and enhance the survival of insect larvae such as porina (Wiseana spp.) (Pottinger 1969, Fenemore \& Allen 1969) and grass grub (Costelytra zealandica) (East \& Willoughby 1980).

Late spring - early summer herbage surplus can be controlled by subdivision, and by grazing management options such as set stocking (Clark et al. 1982), or preferentially grazing steep land and using fast rotations (Sheath et al. 1984), or by the use of different grazing animals, especially cattle (Suckling et al. 1975), or goats (Clark et al. 1984).

Chemicals have also been used to control surplus growth by changing botanical composition. Paraquat at low rates suppresses Qrass growth and legume dominant pastures develop (Palmer 1968; Williams 1968) that result in higher lamb growth rates (Palmer 1967; Taylor \& Arnst 1968; Williams \& Palmer 1970). Mefluidide suppresses grass seed head formation, maintaining pasture quality (Jackson et al. 1980, Field \& Whitford 1980) and increased lamb growth rates (Goold et al. 1982). Both paraquat and mefluidide decrease total herbage accumulation, but enhance pasture quality and allow surplus herbage of high quality to be used later in the summer.

Recently a range of new grass control herbicides has become available including sethoxydim (Naish et al. 1982) and Dowco 453. The aim of this work was to 
compare the effectiveness of these new chemicals to enhance legume content of hill country pastures and to thereby produce high quality forage during mid and late summer.

\section{METHODS}

Two field trials were conducted at Ballantrae, Grasslands Division hill country research area, near Woodville. Monthly rainfall during the trials was recorded (Table 1).

Table 1: MONTHLY AND TOTAL RAINFALL (MM) FOR NOVEMBER TO APRIL DURING THE TRIAL PERIOD AND THE 14 YEAR AVERAGE.

\begin{tabular}{lccccccc}
\hline & Nov & Dec & Jan & Feb & Mar & Apr & Total \\
\hline Trial 1 & 91 & 178 & 79 & 56 & 75 & 110 & 589 \\
Trial 2 & 72 & 108 & 42 & 81 & 107 & 51 & 461 \\
Average & 93 & 113 & 81 & 69 & 96 & 89 & 541 \\
\hline
\end{tabular}

Trial 1 was on a southern aspect in a set stocked pasture of 22" slope. The soil, a Wilford silt loam, is an intergrade from mudstone, of moderate fertility, with Olsen $\mathrm{P}$ 12 , and $\mathrm{pH}$ 5.4. Pasture composition at spraying was $14 \%$ legume, white clover (Trifolium repens) and Lotus pedunculatus, $14 \%$ dead matter, $72 \%$ grasses $(12 \%$ Lolium spp, $12 \%$ other high fertility grasses; cocksfoot (Dactylis glomerata), Yorkshire fog (Holcus lanatus) and Poa species; 48\% browntop (Agrostis spp.) and other 'low fertility tolerant' grasses, sweet vernal (Anthoxanthum odoratum) and crested dogstail (Cynosurus cristatus). Plots $1.5 \times 3.0 \mathrm{~m}$, were spelled one week before spraying on 1 December 1982, when herbage was $20 \mathrm{~mm}$ high. Herbicides used to suppress grass growth were paraquat dichloride salt ('Gramoxone') at $140 \mathrm{~g}$ active ingredient (a.i.)/ha with a non-ionic surfactant ('Agral LN') at $0.6 \% \mathrm{v} / \mathrm{v}$; sethoxydim as an emulsifiable concentrate ('Alloxal S') at 50, 100, 150 and $200 \mathrm{~g}$ a.i./Tha with an emulsifiable crop oil $(1 \% \mathrm{v} / \mathrm{v})$. Herbicides were applied in water at 300 litres/ha at $220 \mathrm{kPa}$. There were 5 replicates. The trial area was fenced. At regular intervals after treatment, $0.5 \mathrm{~m}^{2}$ sample was cut from each plot for determination of dry matter, botanical composition and in vitro digestibility, and the trial site grazed with sheep for 24 hours.

Trial 2 was on a south west aspect of 13" slope, in the same paddock as trial 1. Pasture composition at spraying was 10\% legume (white clover, suckling clover, suckling clover ( $T$. dubium), and Lotus in about equal proportions) $7 \%$ other broadleaves species and $81 \%$ grasses $(24 \%$ Lolium, $20 \%$ sweet vernal, $19 \%$ browntop, $12 \%$ crested dogstail). Plots $1.5 \times 4 \mathrm{~m}$ were spelled 10 days before spraying on 28 November 1983 when herbage was $30 \mathrm{~mm}$ high. Herbicides used were a mixture of paraquat dichloride salt + diquat dibromide salt ('Spraygrow') at $150+$ $25 \mathrm{~g}$ a.i./ha respectively; sethoxydim at 50,100 and $150 \mathrm{~g}$ a.i./ha with $1 \% \mathrm{v} / \mathrm{v}$ crop oil, and Dowco 453 (2-[4-(3-chloro-5-trifluromethyl-2-pyridyloxy)phenoxy] propionic acid as the ethoxy ethyl ester) at 25 and $50 \mathrm{~g}$ a.i./ha with $1 \% \mathrm{v} / \mathrm{v}$ crop oil. Treatments were replicated 4 times. The trial was fenced and managed as in Trial 1.

\section{PASTURE RESPONSES TO CHEMICALS}

Legume content was significantly increased by the chemicals during the first 6 weeks following application (Table 2). Sethoxydim and Dowco 453 at $50 \mathrm{~g}$ a.i./.ha were as effective as the recommended rate of paraquat $(150 \mathrm{~g} / \mathrm{ha})$. In the second 6 week period the legume content was greater than in the controls, but were similar by autumn. 
Table 2: PERCENT LEGUME (DRY WEIGHT) FOLLOWING HERBICIDE TREATMENT FOR TRIALS 1 AND 2.

\begin{tabular}{|c|c|c|c|c|c|c|c|}
\hline \multirow{2}{*}{ Treatment } & \multirow{2}{*}{$\begin{array}{c}\text { Rate } \\
\text { (g/ha) }\end{array}$} & \multicolumn{3}{|c|}{ Trial 1} & \multicolumn{3}{|c|}{ Trial 2} \\
\hline & & 12 Jan & 1 Mar & 18 May & 20 Jan & $1 \mathrm{Mar}$ & $7 \mathrm{M} \mathrm{a} \mathrm{y}$ \\
\hline Control & - & 29 & 30 & 7 & 12 & 8 & 2 \\
\hline Paraquat & 140 & 38 & 27 & 8 & - & - & \\
\hline $\begin{array}{c}\text { Paraquat + } \\
\text { diquat }\end{array}$ & $\begin{array}{c}150+ \\
25\end{array}$ & $=$ & $=$ & - & 27 & 14 & 4 \\
\hline \multirow[t]{4}{*}{ Sethoxydim } & 50 & 40 & 38 & 8 & 24 & 13 & 4 \\
\hline & 100 & 44 & 34 & 7 & 31 & 18 & 3 \\
\hline & 150 & 51 & 39 & 12 & 25 & 13 & 3 \\
\hline & 200 & 61 & 31 & 11 & - & - & - \\
\hline \multirow[t]{2}{*}{ Dowco } & 25 & - & $=$ & - & 16 & 10 & 2 \\
\hline & 50 & - & - & - & 27 & 12 & 2 \\
\hline LSD (0.05) & & 12 & NS & NS & 8 & NS & NS \\
\hline
\end{tabular}

NS, non significant

Herbage accumulation was depressed by 16 to $\mathbf{4 5} \%$, depending on treatment, during the first 6 weeks following application (Table 3, 4). During this period untreated plots had herbage accumulation rates of 95 and $110 \mathrm{~kg} \mathrm{DM} / \mathrm{ha} /$ day in the 2 trials. The lowest herbage accumulation rates of treated plots were 53 and $70 \mathrm{~kg}$ $\mathrm{DM} / \mathrm{ha}$ /day in the two trials. This is in excess of animal requirements which may reach $40 \mathrm{~kg} \mathrm{DM} / \mathrm{ha} /$ day during this period. Total herbage accumulations were similar to untreated for subsequent harvests and importantly there was no carry-over effect during winter. Early spring growth was reduced by the higher rates of sethoxydim (150 and $200 \mathrm{~g} / \mathrm{ha}$ ).

Table 3: TOTAL HERBAGE ACCUMULATION (kg DM/ha) AND DEAD MATTER (\% IN BRACKETS) AT EACH HARVEST DATE FOR THE HERBICIDE TREATMENTS IN TRIAL 1.

\begin{tabular}{lccccccc}
\hline Herbicide & \multicolumn{7}{c}{ Harvest date } \\
& $\begin{array}{c}\text { Rate } \\
\text { (g/ha) }\end{array}$ & $\mathbf{1 2 . 1 . 8 2}$ & 1.3 .83 & 18.5 .83 & $\mathbf{1 . 9 . 8 3}$ & $\mathbf{2 8 . 1 0 . 8 3}$ & Total \\
\hline Control & - & $4010(4)$ & $2630(17)$ & $1400(14)$ & $610(6)$ & $1460(2)$ & 10110 \\
Paraquat & 140 & $2580(7)$ & $2770(8)$ & $1210(7)$ & $590(6)$ & $1420(2)$ & 8570 \\
Sethoxydim & 50 & $2790(6)$ & $2880(9)$ & $1160(5)$ & $550(6)$ & $1300(3)$ & 8680 \\
& 100 & $2610(7)$ & $2610(10)$ & $1350(6)$ & $700(5)$ & $1560(2)$ & 8830 \\
& 150 & $2350(6)$ & $2870(10)$ & $1160(9)$ & $590(5)$ & $1150(2)$ & 8120 \\
& 200 & $2220(5)$ & $2460(8)$ & $730(5)$ & $560(6)$ & $1190(1)$ & 7160 \\
LSD (0.05) & & $590(N S)$ & $N S\left(^{* *}\right)$ & $560(* *)$ & $N S(N S)$ & $330(N S)$ & 1810 \\
\hline
\end{tabular}

NS, not significant; $\cdots$ significant $P<0.01$

During late summer dead matter contents of pastures were significantly lower in the treated plots (Tables 3,4). Green herbage accumulation on treated pasture was higher than untreated during the late summer in trial 1. This was associated with higher than average rainfall during summer (Table 1). Even in a drier than average summer (trial 2), green herbage accumulation was not reduced in treated plots during late summer. 
Table 4: TOTAL HERBAGE ACCUMULATION (kg DM/ha) AND DEAD MATTER $(\%$ IN BRACKETS) AT EACH HARVEST DATE FOR THE HERBICIDE TREATMENTS IN TRIAL 2.

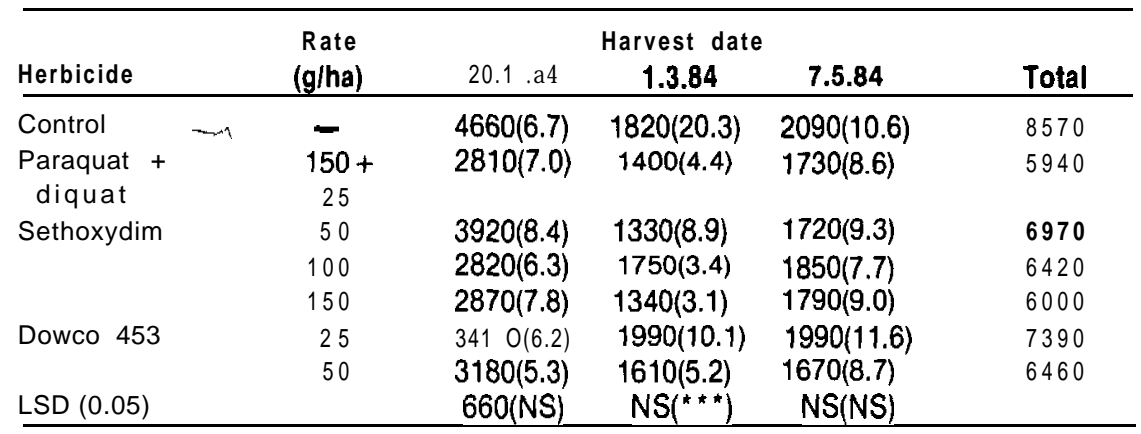

NS, non significant; * * significant $P<0.001$

Table 5: GRASS AND CLOVER SEED HEADS (PER M $^{2}$ ) IN MID JANUARY 6 WEEKS AFTER HERBICIDE APPLICATION.

\begin{tabular}{|c|c|c|c|c|c|}
\hline \multirow[b]{2}{*}{ Treatment } & \multirow[b]{2}{*}{$\begin{array}{c}\text { Rate } \\
\text { (g/ha) }\end{array}$} & & \multicolumn{2}{|c|}{ Trial 1} & \multirow{2}{*}{$\begin{array}{l}\text { Trial } 2 \\
\text { Grass }\end{array}$} \\
\hline & & & Clover & Grass & \\
\hline Set stocked & - & & 2 & 77 & 108 \\
\hline Control & - & & 30 & 1060 & 370 \\
\hline Paraquat & $\overrightarrow{140}$ & & 35 & 260 & - \\
\hline $\begin{array}{l}\text { Paraquat + } \\
\text { diquat }\end{array}$ & $\begin{array}{c}150+ \\
25\end{array}$ & & - & - & 40 \\
\hline \multirow[t]{4}{*}{ Sethoxydim } & 50 & & 51 & 114 & 67 \\
\hline & 100 & 1 & 69 & 43 & 10 \\
\hline & 150 & & 56 & 53 & 14 \\
\hline & 200 & & 95 & 30 & - \\
\hline \multirow[t]{2}{*}{ Dowco } & 25 & & $=$ & - & 110 \\
\hline & 50 & & - & - & 57 \\
\hline LSD $\quad(0.05)$ & & & $\overline{45}$ & 218 & 76 \\
\hline
\end{tabular}

Grass seed head formation was severely reduced by all treatments (Table 5). Grass head numbers were high on untreated plots spelled for 6 weeks compared to the set stocked continuously grazed pasture adjacent to the trial area. Clover seed head numbers on untreated plots increased with spelling (compared with continuously grazed pasture). Treated plots had significantly more clover seed heads than untreated plots (Table 5). Reseeding of white clover could occur during a6 week spelling from grazing (Suckling, 1954).

In vitro digestibility of treated plots was increased by 3 to $5 \%$ units during early summer, and 1 to $4 \%$ units during late summer (Table 6 ).

The effect of the chemical treatments on grass species was studied in the second trial. There was a trend for sethoxydim at $150 \mathrm{~g} / \mathrm{ha}$ to reduce ryegrass content while browntop increased. In contrast, Dowco 453 increased the ryegrass content and reduced the browntop content.

There was no significant change in the botanical composition of broadleaf herbs and weeds following chemical treatments. 
Table 6: IN VITRO DM DIGESTIBILITY (\%) OF TOTAL HERBAGE AT TWO HARVEST DATES FOR DIFFERENT HERBICIDE TREATMENTS IN TRIALS 1 AND 2.

\begin{tabular}{|c|c|c|c|c|c|}
\hline \multirow[b]{2}{*}{ Herbicide } & \multirow[b]{2}{*}{$\begin{array}{c}\text { Rate } \\
\text { (g/ha) }\end{array}$} & \multicolumn{2}{|c|}{ Trial 1} & \multicolumn{2}{|c|}{ Trial 2} \\
\hline & & 12.1 .83 & 1.3 .83 & 20.1 .84 & 1.3 .84 \\
\hline Control & - & 63.4 & 64.3 & 63.0 & 68.9 \\
\hline Paraq uat & 140 & 67.9 & 67.3 & - & - \\
\hline $\begin{array}{c}\text { Paraquat }+ \\
\text { diquat }\end{array}$ & $\begin{array}{c}150+ \\
25\end{array}$ & - & - & 67.8 & 73.2 \\
\hline \multirow[t]{4}{*}{ Sethoxydim } & 50 & 66.2 & 64.2 & 66.1 & 72.8 \\
\hline & 100 & 69.4 & 65.8 & 68.4 & 72.7 \\
\hline & 150 & 68.0 & 65.3 & 68.8 & 72.9 \\
\hline & 200 & 69.0 & 65.0 & - & - \\
\hline \multirow[t]{2}{*}{ Dowco 453} & 25 & - & - & 67.1 & 72.0 \\
\hline & 50 & - & - & 67.6 & 73.5 \\
\hline LSD $\quad(0.05)$ & & 2.3 & NS & 1.5 & 2.5 \\
\hline
\end{tabular}

NS, non significant

The new chemicals are as effective as paraquat, and offer the advantage of maintaining pastures in a green condition, after application, compared to the brown appearance after paraquat use. The factor governing choice of chemical should be cost.

\section{COSTS}

The treatment cost depends on both the chemical and application cost. Paraquat or paraquat/diquat treatment at 140 to $175 \mathrm{~g} / \mathrm{ha}$ would cost $\$ 7$ to $\$ 12 / \mathrm{ha}$, and sethoxydim at $50 \mathrm{~g} / \mathrm{ha}, \$ 12 / \mathrm{ha}$ for the chemical. Application costs vary on the type of aircraft (helicopters are more expensive than fixed-wing aircraft); distance from air strip; size of area to be treated, and particularly on the volume of carrier or water used to dilute the chemical.

The less water used, the lower the costs. With the current recommended water rate for these products being 200-300 litreslha, the cost of application would exceed the chemical costs. At 250 litreslha application would cost $\$ 25 /$ ha, compared with $\$ 10$ and $\$ 5 /$ ha for 50 and 10 litreslha ULV (ultra low volume) respectively. Future research must test the effectiveness of these chemicals applied at low water rates. Sethoxydim could be formulated in oil for ULV application and used without water just as certain formulations of 2,4-D are currently used for thistle control in hill country.

Thus treatment costs of less than $\$ 20 /$ ha are likely if low volume applications are effective.

\section{DIET CONTRIBUTION}

White clover is markedly superior to grass species in feeding value with sheep liveweight gains nearly double those obtained from perennial ryegrass (Ulyatt, 1981). The addition of white clover to grasses has consistently improved the feeding value compared with grasses alone, the response being proportional to the amount of clover in the pasture (Rattray \& Joyce, 1974). Pasture allowance trials (Jagusch et al., 1979) have shown that the high growth rates required for both replacement and prime lambs are achieved at lower pasture allowances on legume compared with grass swards.

The effect of seasonal variation in sward legume content on legume in the diet for hill country ewes was studied at Ballantrae (Clark \& Ulyatt 1984). When sheep 
were presented with white clover in a short sward they were unable to actively select; however, when presented in paraquat sprayed 'strips' containing $70-80 \%$ white clover dietary content of white clover is significantly increased (Clark \& Harris 1984). Weaned lambs may be better able to select white clover than older ewes (Geenty \& Sykes, 1981).

The increased legume content of the experimental swards can be predicted to increase the dietary content of grazing sheep by a similar margin, (Clark et al. 1982) with likely increases on animal production. Presentation of 'strips' of high-clover content could further increase dietary content of clover.

The small increases in in Vitro DM digestibility with herbicide treatment (Table 6) are consistent with the small changes in dead matter on treated swards (Tables 3 and 4 ) and the small differences in DM digestibility between live white clover and live grass leaf.

\section{IMPLICATIONS}

The use of chemicals to manipulate the legume content of pastures is not a new idea, although to date there has been a low adoption rate by farmers. The technique allows surplus herbage produced in late spring - early summer to be accumulated as legume dominant, low dead matter content herbage available in mid to late summer when lambs are being finished and ewes flushed before mating. Additional benefits could be to provide special purpose pasture for grazing when ryegrass staggers is a problem (Keogh 1973, 1983). By increasing the grazing pressure on the rest of the farm, while sprayed areas are spelled, pasture cover will be reduced, offering the possibility of reduced scrub invasion and high mortality of porina and grass grub larvae.

Pastures in summer moist regions, or in years when late spring surplus of herbage occurs, that have moderate phosphate levels, reasonable legume contents and probably south facing or have good moisture retention would be suitable for treatment. Suitable sites should receive phosphate and sulphur fertiliser in spring before treatment. The suggested time of application of chemicals to browntop dominant hill pastures is mid to late November, once excess herbage accumulation is evident and before seed heads emerge in early December.

Farmers need to re-evaluate the benefits of using chemicals to increase legume content on a portion of the farm. If ULV application is feasible the technique should be cost effective and demonstrations to verify the benefits and costs would be required.

\section{ACKNOWLEDGEMENTS}

We thank David McFarland for technical assistance, Rhian Taylor for in vitro digestibilities, and Yvonne Gray and herbage laboratory staff for botanical dissections.

\section{REFERENCES}

Clark, D.A.; Harris, P.S. 1984. N.Z. J. agric. Res: (submitted).

; Lambert, M.G.; Chapman, D.F. 1982. Proc. N.Z. Grass/d Ass. 43:

205214.

; Rolston, M.P.; Lambert, M.G.; Budding, P.J. 1984: Ibid 45: 160-167.

Ulyatt, M.J. 1984. Proc. USA/NZIAustralian Workshop on Forage

legumes for Energy-Efficient Animal Production. (In press).

East, R.; Willoughby, B.E. 1980. N.Z. J. agric. Res. 23: 547-563.

Fenemore, P.G.; Allen, V.A.L. 1969. /bid 72: 146-161.

Field, R.J.; Whitford, A.R. 1980. Proc. 33rd N.Z. Weed Pest Cont. Conf:: 74-78.

Geenty, K.G.; Sykes, A.P. 1981. Proc. N.Z. Soc. Anim. Prod. 41: 235-241. 
Goold, G.J.; Jagusch, K.T.; Farquhar, P.; MacLean, K.S. 1982. Proc. N.Z. Soc. Anim. Prod. 42: 169-172.

Jackson, I.R.; O'Connor, B.P.; Jacobson, D.J.I. 1980. Proc. 33rd N.Z. Weed Pest Cont. Conf.: 67-73.

Jagusch, K.T.; Rattray, P.V.; Winn, G.W. 1979. Proc. Agron. Soc. of N.Z. 9: 7-10.

Keogh, R.G. 1973. N.Z. J. exp. Agric. 1: 51-57.

1983. Proc. N.Z. Grassld Ass. 44: 248-250.

Korte, C.J. 1982. /bid 43: 80-84.

Lambert, M.G.; Clark, D.A. 1981. Proc. 1981 Fertilizer Seminar East Coast Fertilizer Co. Ltd.: 33-36.

; Grant, D.A.; Costall, D.A. 1983. N.Z. J. agric Res. 26: 95-108 Naish, R.W.; Iwataki, I.; Ishikawa, M. 1982. Proc. 35fh N.Z. Weed Pesf Cont. Cont.: 274-275.

Palmer, P.C. 1967. Proc. 20th N.Z. Weed Pest Cont. Soc. Conf.: 50-57.

1968. Proc. 21st N.Z. Weed Pest Cont. Soc. Conf.: 120-127.

Pottinger, R.P. 1969. Proc. N.Z. Grassld Ass. 30: 102-113.

Rattray, P.V.; Joyce, J.P. 1974. N.Z. J. agric. Res. 17: 401-406.

Sheath, G.W.; Webby, R.W.; Pengelly, W.J. 1984. Proc. N.Z. Grass/d Ass. 45: 199-206.

Suckling, F.E.T. 1954. N.Z. J. Sci. Tech. 36A: 237-273. 1975. N.Z. J. exp. Agric. 3: 351-436.

Taylor: R.; Arnst, R.N. 1968. Proc. 21st N.Z. Weed Pest Cont. Soc. Conf.: 114-119.

Ulyatt, M.J. 1981. N.Z. Agric. Sci. 15: 200-205.

Williams, P.P. 1968. Proc. 21st N.Z. Weed Pest Cont. Soc. Conf.: 128-137. ; Palmer, P.C. 1970. Proc. N.Z. Grass/d Ass. 37: 96-109. 